\title{
Racial dis parities in pre valence, determinants, and impacts of COVID-19 in pregnancy: Protocol for a study using data from New Jersey hospitals
}

Slawa Rokicki, $\mathrm{PhD}^{1}$, Pauline Nguyen, $\mathrm{MD}^{2}$, Alaine Sharpe, $\mathrm{MD}^{2}$, Dyese Taylor, $\mathrm{MD}^{2}$, Suzanne Spernal, DNP2 , Archana Raghunath, $\mathrm{MPH}^{3}$, Leslie Kantor, $\mathrm{PhD}, \mathrm{MPH}^{3}$

May 2021

1 Rutgers School of Public Health, Department of Health Behavior, Society, and Policy, Piscataway, $\mathrm{NJ}$

${ }^{2}$ RWJBarnabas Health, West Orange, NJ

${ }^{3}$ Rutgers School of Public Health, Department of Urban-Global Health, Newark, NJ

\section{Corresponding author:}

\section{Slawa Rokicki}

Rutgers School of Public Health

683 Hoes Lane West, Office 232

Piscataway, NJ 08854

Email: slawa.rokicki@ rutgers.edu

ORCID: https://orcid.org/0000-0001-9176-373X 


\begin{abstract}
Introduction

Racial and ethnic disparities in COVID-19 related infections, hospitalizations, and deaths have been well-documented. However, little research has examined racial and ethnic disparities in COVID-19 prevalence, determinants, and impacts among pregnant women. Within the United States, New Jersey was an early epicenter of the pandemic and experienced high rates of disease in the fall of 2020.
\end{abstract}

\title{
Methods
}

This study uses data from two New Jersey hospitals, which implemented universal testing of COVID-19 of pregnant women admitted for labor and delivery starting in March 2020. We will estimate prevalence of COVID-19 between March 2020 and November 2020 and compare prevalence rates across race and ethnicity. We will conduct multivariable logistic regression analysis to examine the associations of COVID-19 infection with patient demographic and health status predictors. We will also use multivariable linear and logistic regressions to examine the impact of COVID-19 symptomatic and asymptomatic infection on maternal and infant birth outcomes.

\section{Discussion}

This study will generate important policy implications on birth equity in the time of COVID-19 and guide future research studies related to COVID-19 in pregnant women. Results of this study will help to guide interventions and policies to center safe, accessible, and equitable maternity care within the strategic response to the pandemic. 
medRxiv preprint doi: https://doi.org/10.1101/2021.05.23.21257672; this version posted May 25, 2021. The copyright holder for this preprint (which was not certified by peer review) is the author/funder, who has granted medRxiv a license to display the preprint in perpetuity. It is made available under a CC-BY-NC-ND 4.0 International license .

\section{Introduction}

Since its emergence in late 2019, the severe acute respiratory syndrome coronavirus 2 (SARSCoV-2) that causes novel coronavirus disease (COVID-19) has infected over 163,720,868 people worldwide, approximately one-fifth of whom are in the United States $(32,972,982)$ as of early May 2021. ${ }^{1-4}$ Within the United States, New Jersey was an early epicenter of the pandemic, and once again experienced high rates of disease in the fall of $2020 .^{5}$

Despite significant advancements in our understanding of SARS-CoV-2 infection, the effects of COVID-19 on pregnant women and pregnancy outcomes remains understudied. Due to altered physiology and immune function, pregnant women and their fetuses are generally considered a high-risk population during infectious disease outbreaks. ${ }^{6-10}$ Available evidence suggests that the incidence of preterm births, low birth weight, Cesarean section, and ICU admission appears higher among pregnant women with COVID-19 than among women without COVID-19.8,11-16

Racial disparities in COVID-19 related infections, hospitalizations, and deaths have been welldocumented. ${ }^{17,18}$ Disparities reflect the health consequences of the social, environmental, and structural effects of racism, including differences in prevalence of underlying chronic conditions and exposure to impacts of the social determinants of health including access to medical insurance, wealth, and employment as essential employees. ${ }^{19,20}$ However, few studies have examined racial disparities in perinatal outcomes of COVID-19. ${ }^{19,21}$ More research is critical for developing clinical care guidelines that promote birth and reproductive health equity.

New Jersey is a particularly important setting to study disparities in COVID-19 during pregnancy because of its diverse population and the high incidence of COVID-19 that affected the population of New Jersey in the early months of the pandemic. ${ }^{5}$ To date, there have been few studies on COVID-19 in pregnant women in New Jersey. ${ }^{22}$ Little is known about how many pregnant women 
medRxiv preprint doi: https://doi.org/10.1101/2021.05.23.21257672; this version posted May 25, 2021. The copyright holder for this preprint (which was not certified by peer review) is the author/funder, who has granted medRxiv a license to display the preprint in perpetuity.

It is made available under a CC-BY-NC-ND 4.0 International license .

in New Jersey contracted the disease at various time points in the pandemic, the factors that affect

likelihood of infection in pregnant women, and whether symptomatic status and pre-existing conditions influence the outcomes of their pregnancies or their infants' health. This study will examine these research questions using data from hospital records in a region with high incidence of COVID-19 that implemented universal COVID-19 testing of pregnant women.

\section{Methods}

\section{Goal and objectives}

The study will use data from two New Jersey hospitals collected between March and November 2020. The primary study objectives are:

1. To determine the prevalence of COVID-19 in pregnant women in two New Jersey hospitals and assess how prevalence changed from March to November 2020

2. To assess disparities in rates by race and ethnicity, geography of residence (ZIP code), age, body mass index (BMI), length of gestation, parity, insurance status, and pre-existing health conditions

3. To examine differences in maternal and infant health outcomes among women positive for COVID-19 who were symptomatic on admission, women positive for COVID-19 who were asymptomatic on admission, and women negative for COVID-19

Secondary study objectives are: 
medRxiv preprint doi: https://doi.org/10.1101/2021.05.23.21257672; this version posted May 25, 2021. The copyright holder for this preprint (which was not certified by peer review) is the author/funder, who has granted medRxiv a license to display the preprint in perpetuity.

It is made available under a CC-BY-NC-ND 4.0 International license .

1. To examine differences in maternal and infant health outcomes between diabetic pregnant women with symptomatic and asymptomatic COVID-19 and diabetic women negative for COVID-19

\section{Study population}

The study will use data from the electronic medical records (EMR) of all women who were admitted for labor and delivery experience at the Newark Beth Israel (NBI) and Clara Maass Medical Centers (CMMC), between March 17th, 2020 and November 20th, 2020. Both hospitals are located in Essex county, New Jersey, which has a diverse and low-income population. In 2019, $21 \%$ of births in Essex county were to White non-Hispanic mothers, $40 \%$ were to Black nonHispanic, $30 \%$ were to Hispanic mothers of any race, and $9 \%$ were to Asian or other races. ${ }^{23} 41 \%$ of all births were to mothers with Medicaid insurance. $46 \%$ of births were to foreign-born mothers.

\section{Project management}

Our collaborative multi-site research team brings together the Rutgers University School of Public Health, NBI, and CMMC. The partners from these hospitals are involved in the research and will collaborate on the study design, data extraction and transfer, and interpretation of results.

\section{Data and measures}

Both NBI and CMMC implemented universal testing of COVID-19 of pregnant women admitted for labor and delivery in March 2020. Data will be extracted from two sources: (1) NBI electronic medical records and (2) CMMC electronic medical records. The medical records reflect birth hospitalizations, including both women's records and infant records. Hospital administrators in each hospital will provide access to these records. The records will be extracted by our partners on 
medRxiv preprint doi: https://doi.org/10.1101/2021.05.23.21257672; this version posted May 25, 2021. The copyright holder for this preprint (which was not certified by peer review) is the author/funder, who has granted medRxiv a license to display the preprint in perpetuity.

It is made available under a CC-BY-NC-ND 4.0 International license .

the research team at each respective hospital and transferred to the Rutgers School of Public Health. We anticipate 1300 records from each hospital, with approximately 50 COVID positive cases.

The following variables will be extracted from the electronic medical record. COVID-19 status will be extracted and categorized as positive symptomatic, positive asymptomatic, negative. Demographic and health status variables extracted include date of admission, race/ethnicity, ZIP code, age (in years), BMI, length of gestation upon admission for labor and delivery, parity, insurance status, birth weight, smoking status, history of preterm birth, history of hypertension, and history of diabetes. Outcome variables include type of delivery (vaginal, c-section), depression/anxiety (as measured by the Postnatal Edinburgh Depression Scale ${ }^{24}$ ), admittance to ICU (mother), any supplemental oxygen used, vascular disease, fetal distress, newborn respiratory distress syndrome, admission to NICU (infant), APGAR score (infant), breastfeeding status, and infant weight gain.

\section{Ethics approvals and data security considerations}

Institutional Review Board (IRB) approvals have been obtained at each institution (Rutgers School of Public Health ID\# Pro2020002959; NBI IRB\#2021.19; CMMC IRB R2021-01CMMC). As this study is a retrospective chart review, an exemption for consent to access patient data was obtained.

This research study presents minimal risks to study subjects. We will not collect subject names, social security numbers, or medical record numbers but the data will include protected health information in the form of ZIP code and admission date. The shared file will contain random identifier numbers and will be password-protected. The data will be kept securely for 6 years after study closure.

\section{Data analysis plan}


medRxiv preprint doi: https://doi.org/10.1101/2021.05.23.21257672; this version posted May 25, 2021. The copyright holder for this preprint (which was not certified by peer review) is the author/funder, who has granted medRxiv a license to display the preprint in perpetuity.

It is made available under a CC-BY-NC-ND 4.0 International license .

The data analysis will include descriptive statistics (means, medians, standard deviations) of all predictor and outcome variables. We will compare prevalence of COVID-19 over time and across race/ethnicity groups, and compare the prevalence to that of the general population using publicly available data from New Jersey Department of Health. ${ }^{5}$ We will conduct multivariable logistic regression analysis to examine the associations of COVID-19 infection with patient demographic and health status predictors. We will also explore use of multinomial logistic regression to examine determinants across the three categories of COVID-19 infection. Finally, we will use multivariable linear (continuous outcomes) and logistic (binary outcomes) regression to examine the impact of COVID-19 infection (as categorized by symptomatic, asymptomatic, or negative) on maternal and infant birth outcomes. Data analysis will be conducted using Stata v16.

\section{Dissemination of results}

Results will be disseminated in peer reviewed scientific journals and at academic conferences. Research findings will be communicated to relevant state and local policy makers.

\section{Dis cussion}

This multi-site collaborative research study will examine racial disparities in the prevalence of COVID-19 in pregnant women and examine determinants and outcomes of COVID-19 in pregnant women and infants using secondary data from birth records at two New Jersey hospitals with diverse and low-income populations. This study is one of the first to examine SARS-CoV-2 infection prevalence and outcomes among pregnant women in New Jersey, a state that experienced high rates of infection early in the pandemic.

There is a growing body of evidence that COVID-19 has significant health consequences for pregnant women and infants, with increases in maternal deaths, stillbirth, ruptured ectopic 
medRxiv preprint doi: https://doi.org/10.1101/2021.05.23.21257672; this version posted May 25, 2021. The copyright holder for this preprint (which was not certified by peer review) is the author/funder, who has granted medRxiv a license to display the preprint in perpetuity. It is made available under a CC-BY-NC-ND 4.0 International license .

pregnancies, and maternal depression. ${ }^{6,15,16}$ However, little research has examined racial/ethnic disparities in COVID-19 prevalence, determinants, and impacts in pregnancy. ${ }^{19,21}$

This study will generate important policy implications on birth equity in the time of COVID-19 and guide future research studies related to SARS-CoV-2 infection in pregnant women. The study outcomes will help to illuminate larger community prevalence rates and provide insights on population disparities and equity issues among pregnant women. Results of this study will help to guide interventions and policies to center safe, accessible, and equitable maternity care within the strategic response to the pandemic, including the allocation of health care resources to heavily affected populations. 
medRxiv preprint doi: https://doi.org/10.1101/2021.05.23.21257672; this version posted May 25, 2021. The copyright holder for this preprint

(which was not certified by peer review) is the author/funder, who has granted medRxiv a license to display the preprint in perpetuity.

It is made available under a CC-BY-NC-ND 4.0 International license .

\section{References}

1. Johns Hopkins Coronavirus Resource Center. Johns Hopkins Coronavirus Resource Center. Published 2021. Accessed April 23, 2021. https://coronavirus.jhu.edu/map.html

2. Sun P, Lu X, Xu C, Sun W, Pan B. Understanding of COVID-19 based on current evidence. J Med Virol. 2020;92(6):548-551. doi:10.1002/jmv.25722

3. Lai C-C, Shih T-P, Ko W-C, Tang H-J, Hsueh P-R. Severe acute respiratory syndrome coronavirus 2 (SARS-CoV-2) and coronavirus disease-2019 (COVID-19): The epidemic and the challenges. Int J Antimicrob Agents. 2020;55(3):105924. doi:10.1016/j.ijantimicag.2020.105924

4. Wu Y-C, Chen C-S, Chan Y-J. The outbreak of COVID-19: An overview. J Chin Med Assoc. 2020;83(3):217-220. doi:10.1097/JCMA.0000000000000270

5. Department of Health |Communicable Disease Service | New Jersey COVID-19

Dashboard. New Jersey COVID-19 Dashboard. Accessed May 18, 2021. https://www.nj.gov/health/cd/topics/covid2019_dashboard.shtml

6. Dashraath P, Wong JLJ, Lim MXK, et al. Coronavirus disease 2019 (COVID-19) pandemic and pregnancy. American Journal of Obstetrics and Gynecology . 2020;222(6):521-531. doi:10.1016/j.ajog.2020.03.021

7. Juan J, Gil MM, Rong Z, Zhang Y, Yang H, Poon LC. Effect of coronavirus disease 2019 (COVID-19) on maternal, perinatal and neonatal outcome: systematic review. Ultrasound Obstet Gynecol. 2020;56(1):15-27. doi:10.1002/uog. 22088

8. Smith V, Seo D, Warty R, et al. Maternal and neonatal outcomes associated with COVID19 infection: A systematic review. PLOS ONE. 2020;15(6):e0234187. doi:10.1371/journal.pone.0234187

9. Rasmussen SA, Jamieson DJ, Bresee JS. Pandemic influenza and pregnant women. Emerg Infect Dis. 2008;14(1):95-100. doi:10.3201/eid1401.070667

10. Jamieson DJ, Theiler RN, Rasmussen SA. Emerging Infections and Pregnancy. Emerg Infect Dis. 2006;12(11):1638-1643. doi:10.3201/eid1211.060152

11. Gao Y, Ye L, Zhang J, et al. Clinical features and outcomes of pregnant women with COVID-19: a systematic review and meta-analysis. BMC Infectious Diseases. 2020;20(1):564. doi:10.1186/s12879-020-05274-2

12. Delahoy MJ, Whitaker M, O'Halloran A, et al. Characteristics and Maternal and Birth Outcomes of Hospitalized Pregnant Women with Laboratory-Confirmed COVID-19 COVID-NET, 13 States, March 1-August 22, 2020. MMWR Morb Mortal Wkly Rep. 2020;69(38):1347-1354. doi:10.15585/mmwr.mm6938e1 
medRxiv preprint doi: https://doi.org/10.1101/2021.05.23.21257672; this version posted May 25, 2021. The copyright holder for this preprint

(which was not certified by peer review) is the author/funder, who has granted medRxiv a license to display the preprint in perpetuity.

It is made available under a CC-BY-NC-ND 4.0 International license .

13. Yee J, Kim W, Han JM, et al. Clinical manifestations and perinatal outcomes of pregnant women with COVID-19: a systematic review and meta-analysis. Scientific Reports. 2020;10(1):18126. doi:10.1038/s41598-020-75096-4

14. Allotey J, Stallings E, Bonet M, et al. Clinical manifestations, risk factors, and maternal and perinatal outcomes of coronavirus disease 2019 in pregnancy: living systematic review and meta-analysis. BMJ. 2020;370:m3320. doi:10.1136/bmj.m3320

15. Chmielewska B, Barratt I, Townsend R, et al. Effects of the COVID-19 pandemic on maternal and perinatal outcomes: a systematic review and meta-analysis. The Lancet Global Health. 2021;9(6):e759-e772. doi:10.1016/S2214-109X(21)00079-6

16. Vergara-Merino L, Meza N, Couve-Pérez C, et al. Maternal and perinatal outcomes related to COVID-19 and pregnancy: An overview of systematic reviews. Acta Obstetricia et Gynecologica Scandinavica.n/a(n/a). doi:https://doi.org/10.1111/aogs.14118

17. Mackey K, Ayers CK, Kondo KK, et al. Racial and Ethnic Disparities in COVID-19Related Infections, Hospitalizations, and Deaths. Ann Intern Med. 2020;174(3):362-373. doi:10.7326/M20-6306

18. Zelner J, Trangucci R, Naraharisetti R, et al. Racial Disparities in Coronavirus Disease 2019 (COVID-19) Mortality Are Driven by Unequal Infection Risks. Clinical Infectious Diseases. 2021;72(5):e88-e95. doi:10.1093/cid/ciaa1723

19. Onwuzurike C, Diouf K, Meadows AR, Nour NM. Racial and ethnic disparities in severity of COVID-19 disease in pregnancy in the United States. International Journal of Gynecology \& Obstetrics. 2020;151(2):293-295. doi:https://doi.org/10.1002/ijgo.13333

20. Raifman MA, Raifman JR. Disparities in the population at risk of severe illness from COVID-19 by race/ethnicity and income. American journal of preventive medicine. 2020;59(1):137-139.

21. Janevic T, Glazer KB, Vieira L, et al. Racial/Ethnic Disparities in Very Preterm Birth and Preterm Birth Before and During the COVID-19 Pandemic. JAMA Network Open. 2021;4(3):e211816-e211816. doi:10.1001/jamanetworkopen.2021.1816

22. McFarland MJ, McFarland CAS, Hill TD, D'Oria R. Postpartum Depressive Symptoms during the Beginning of the COVID-19 Pandemic: An Examination of Population Birth Data from Central New Jersey. Matern Child Health J. Published online January 25, 2021. doi:10.1007/s 10995-020-03116-w

23. New Jersey Department of Health. New Jersey State Health Assessment Data. Center for Health Statistics; 2021. https://www-doh.state.nj.us/doh-shad/

24. Cox JL, Holden JM, Sagovsky R. Detection of Postnatal Depression: Development of the 10-item Edinburgh Postnatal Depression Scale. The British Journal of Psychiatry. 1987;150(6):782-786. doi:10.1192/bjp.150.6.782 
medRxiv preprint doi: https://doi.org/10.1101/2021.05.23.21257672; this version posted May 25, 2021. The copyright holder for this preprint (which was not certified by peer review) is the author/funder, who has granted medRxiv a license to display the preprint in perpetuity.

\author{
It is made available under a CC-BY-NC-ND 4.0 International license
.
}

